\title{
EDUCATION IN THE HUMANITIES IN MARITIME EDUCATIONAL INSTITUTIONS OF UKRAINE (1973-1983)
}

\author{
Olena Ovchynnikova \\ Postgraduate Student, "Kherson Academy of Continuing Education" \\ of Kherson Regional Council; Assistant at the Department of English in Navigation, \\ Kherson State Maritime Academy, Ukraine \\ e-mail: eovchinnikova22@gmail.com, orcid.org/0000-0002-7184-6535
}

\begin{abstract}
Summary
This paper presents the education in humanities in maritime educational institutions of Ukraine (1973-1983). Maritime transport, the state of education, teaching of the humanities in maritime educational establishments during this period are investigated. The article deals with the analysis of the proportion of the humanities in the total hours of the curriculum and with the subjects which were studied at every year of education in maritime educational institutions of Ukraine during 1973-1983. It appears that small amounts of hours were allocated to the humanities in the curriculum. Among the humanities can be distinguished the study of foreign language, history, literature, social sciences, social geography, etc. Much attention was paid to general special and profiling subjects and also to ideological disciplines, such as the history of the CPSU, Marxist-Leninist philosophy, scientific communism, and atheism. But in general the Soviet fleet developed as well as methods of labor organization and industry management.

Keywords: specialty, curriculum, subject, semester, exam, credit.
\end{abstract}

\section{DOI https://doi.org/10.23856/3927}

\section{Introduction}

The humanities - areas of research, the subject of which is a human as a social (cultural, moral, spiritual) being and everything that is created by him. The teaching of the humanities has an important influence and importance in the process of training specialists in various fields, because education in the humanities forms a person on whose activities depends on the development of society and the country on the whole.

Nevertheless, little attention has been paid to the development of education in the humanities in maritime educational establishments. When analysing curriculums, more attention was paid to special disciplines that form the professional side of the individual. Therefore, the aim of the article is to analyze the teaching of humanities in maritime educational institutions during 1973-1983. To do this, it is necessary to determine hours (as one of the important factor that has influence on the content of education) which are given to the humanities in maritime educational institutions and to investigate the proportion of the humanities in the total hours of the curriculum.

Research approaches: induction, comparison, generalization, analysis and synthesis, mathematical statistical methods. The article is divided into such parts: maritime transport during 1973-1983; the state of education during 1973-1983; teaching of the humanities in maritime educational establishments during 1973-1983.

\section{Maritime transport during 1973-1983}

In the 1970s-1980s hundreds of specialized vessels (container ships, oil bulkers, railway ferries, ships for the transport of heavy cargo) joined the transport fleet, specialized coastal 
complexes were built, which made possible significantly improve the technology of transportation and transshipment of cargo. New methods of labor organization and industry management with the help of automated systems have been greatly developed. The Soviet fleet became an equal partner of many ship-owning companies in the world and was admitted to a number of international organizations. All this was reflected in the educational sphere (1).

\section{The state of education during 1973-1983}

In 1973 the law "Approval of the Basics of the Legislation of the USSR and the Soviet Republics about Public Education" was adopted, recognizing as invalid the Law of the USSR "Strengthening of relations between school and life and the further development of the public education system in the USSR", December $24^{\text {th }}, 1958$ and it was assigned to the Supreme Soviets of the Union Republics to bring into compliance the legislation of the Union Republics with the Basics of the legislation of the USSR and the Union Republics on public education (Lukov, 2005: 218).

Resolutions "On Further Improving of the Management of Secondary Special Educational Institutions and Improving the Quality of Training of Specialists with Secondary Special Education", August 22 2 , 1974 and "Basics of Legislation of the USSR and Union Republics about Public Education" (1973) defined the legal framework for education. Acording to this, secondary special educational institutions had to specialize on a sectoral basis, taking into account the necessary cooperation in training of the specialists. The Council for Secondary Special Education and the State Inspection Department were established under the Ministry of Higher and Secondary Education of the USSR (Liashkevych, 2018: 120). But the rate of lag of the Soviet higher school from the progressive world achievements in scientific and technical, informational, economic and managerial spheres intensified (Lukov, 2005: 218).

\section{Teaching of the humanities in maritime educational establishments during 1973-1983}

Education in the humanities is a cycle of sciences and disciplines that study a person, his personality, culture and society, as well as a person in the field of his spiritual, mental, moral, cultural and social activities.

According to subject features, three groups of sciences can be distinguished: 1) natural sciences (physics, astronomy, geology, physical geography, chemistry, biology, botany); 2) natural sciences and humanities (psychology, ethology, medicine, ecology, economic geography); 3) humanities: classical - literary and art history, grammar, history; modern and recent economics and political economy, law, sociology, social psychology, anthropology, ethnology (including ethnography and folklore) and national science, political science, religion.

To analyze the teaching of the education in the humanities during 1973-1983, we analyzed the curriculums of 1973-1983 of the Kherson branch of the Nikolayev Admiral S. Makarov Shipbuilding Institute in three specialties: "Ship Power Plants" (0525), "Shipbuilding and Ship Repair" ( 0514), "Technology and equipment of welding production" (0504) and curriculums of 1972-1973, 1982-1983 of the Maritime College of the Kherson State Maritime Academy, which in those years was called Kherson Lieutenant Schmidt Naval Training School, specialty №1612 "Maritime Navigation”.

Let's give consideration to the curriculums of 1972-1973, 1982-1983 of the Maritime College of the Kherson State Maritime Academy, specialty № 1612 "Maritime Navigation" (Curriculum of the specialty "Navigation": 1972, 1982). 
Table 1

Education in the humanities of the Maritime College of the Kherson State Maritime Academy (1972-1973, 1982-1983)

\begin{tabular}{|c|c|c|c|c|c|}
\hline $\begin{array}{c}\text { Educa- } \\
\text { tional } \\
\text { year }\end{array}$ & Specialty & $\begin{array}{c}\text { Year of } \\
\text { education }\end{array}$ & $\begin{array}{c}\text { Total } \\
\text { number } \\
\text { of hours }\end{array}$ & $\begin{array}{c}\text { Hours which } \\
\text { are given to the } \\
\text { humanities }\end{array}$ & $\begin{array}{c}\text { The proportion of the humanities in } \\
\text { the total hours of the curriculum, \% }\end{array}$ \\
\hline \multirow{3}{*}{$1972-1973$} & \multirow{3}{*}{1612} & I & - & - & - \\
\cline { 3 - 6 } & & II & 1188 & 192 & 16,16 \\
\cline { 3 - 6 } & & III & 686 & 72 & 10,5 \\
\cline { 3 - 6 } & & IV & 768 & 218 & 28,39 \\
\cline { 3 - 6 } & \multirow{3}{*}{$1982-1983$} & V & 218 & 59 & 27,06 \\
\cline { 3 - 6 } & \multirow{3}{*}{1612} & I & 1170 & 264 & 22,56 \\
\cline { 3 - 6 } & & II & 996 & 348 & 34,94 \\
\cline { 3 - 6 } & & IV & 645 & 152 & 16,08 \\
\hline
\end{tabular}

During the analysis we saw that in the curriculum of the Maritime College of the Kherson State Maritime Academy the subjects are divided into three cycles: general education cycle, general technical cycle, special cycle, which included general and profile subjects and electives. We were interested in the subjects of the humanities, the number of hours which are given to the humanities and proportion of this number in the total number of hours of the curriculum.

In the 1972-1973 academic year was such proportion of the humanities in the total hours of the curriculum: $16,16 \%$ in the second year, $10,5 \%$ in the third year, $28,39 \%$ in the fourth year, and $27,06 \%$ in the fifth year.

In the curriculum of 1972-1973 in the second year, the humanities included: political economy -90 hours or $7,56 \%$ of the total number of hours with the exam in the IV semester; English - 102 hours or 8,59\% with the credit in the third semester. 66 hours were given to English as elective. In the third year: English - 72 hours or 10,5\% with the credit in the VII semester. Electives included 18 hours of English and 36 hours of the discipline of socio-political work on the vessels of the Ministry of the Navy. In the fourth year: English -76 hours or 9,9\%, maritime law -56 hours or $7,29 \%$, economics, organization and planning of maritime transport 86 hours; or 11,2\%. Elective included 22 hours of English. In the 5th year: English - 45 hours or $20,64 \%$ with the exam in the IX semester; economics, organization and planning of maritime transport -14 hours or $6,42 \%$. As an elective, 7 hours were given to English.

In the 1982-1983 academic year, 22,56\% were given for humanities in the first year, $34,94 \%$ in the second year, $16,08 \%$ in the third year, and $47,22 \%$ in the fourth year.

In the curriculum of 1982-1983 in the first year the humanities included: history 96 hours, which was $8,21 \%$ of the total number of hours; literature -108 hours with a rate of $9,23 \%$ with the exam in the second semester; English - 60 hours with a rate of 5,13\%. Electives were 30 hours of English and 60 hours of Russian. In the second year: history -96 hours or $9.64 \%$ with an exam in the IV semester; literature -84 hours or $8,43 \%$ with the exam in the IV semester; English language - 108 hours or $10,84 \%$ with the exam in the third semester; economic and social geography of the world -60 hours or $6,02 \%$. Electives were 30 hours of Russian and 30 hours of the discipline of socio-political work in the vessels of the Ministry of the Navy. In the third year: social sciences -71 hours or $7,51 \%$ with the state exam in the VI semester; English - 81 hours or 8,57\%. Electives were 27 hours of English and 27 hours 
of the basics of Marxist-Leninist ethics and aesthetics. In the 4th year: English - 95 hours or $14,29 \%$ with an exam in the VIII semester; Soviet law - 38 hours or 5,71\%; economy, organization and planning of maritime transport - 141 hours or 21,2\%. Electives were 19 hours of English and 11 hours of Marxist-Leninist ethics and aesthetics.

Next, let's give consideration to the curriculums of 1973-1983 of the Kherson branch of the Nikolayev Shipbuilding Institute named after Admiral S. Makarov in three specialties: "Ship power plants" (0525), "Shipbuilding and ship repair" (0514), "Technology and equipment of welding production" ( 0504) (Curriculum of the Kherson branch of the Nikolaev Admiral S.O. Makarov Shipbuilding Institute: 1973-74, 1974-75, 1975-76, 1976-77, 1977-78, 1978-79, 1979-80, 1980-81, 1983-84). During the examination the curriculums, we decided to select 3 periods inside this time range (1973-1983), as follows 1973-1974, 1978-1979, 1983-1984.

In the 1973-1974 academic year, $28,13 \%$ of total number of hours was given for humanities in the first year, $25,7 \%$ in the second year, $18,75 \%$ in the third year, and $10,18 \%$ in the fourth year in the specialties 0514,0525 and $10,22 \%$ in the specialty 0504 , in the 5 th year there was no time for the study of humanities, in the 6 th year $-21,08 \%$ in the specialty $0514,20,83 \%$ in the specialty $0504,8,56 \%$ in the specialty 0525 .

In the curriculum of 1973-1974 in the first year, the humanities included: history of the CPSU -80 hours, which was $15,63 \%$ of the total number of hours with exams in the I and the II semesters; foreign language - 64 hours with a rate of $12,5 \%$ with credits in the I and the II semesters. In the second year: Marxist-Leninist philosophy -70 hours or $12,5 \%$ with exams in the III and the IV semesters; foreign language - 70 hours or 12,5\% with exams in the III and the IV semesters. In the third year: political economy -105 hours or $18,75 \%$ with exams in the $\mathrm{V}$ and the VI semesters. In the 4 th year: scientific communism 57 hours or $10,18 \%$ in the specialty 0514,0525 and 57 hours or $10,22 \%$ in the specialty 0504 with the exam in the VII semester and the credit in the VIII semester. In the 5th year, there were not hpurs for the study the humanities. In the VI course: economics of the shipbuilding industry -38 hours or $11,45 \%$ with the exam in the XI semester; basics of labor legislation -32 hours or $9,64 \%$ with the credit in the XII semester in the specialty 0514 ; economics of the shipbuilding industry -28 hours or $11,3 \%$ with the exam in the XI semester; basics of labor legislation - 32 hours or $9,52 \%$ with the credit in the XII semester in the specialty 0504 ; basics of labor legislation -32 hours or $8,56 \%$ with the credit in the XII semester in the specialty 0504.

In the 1978-1979 academic year, 22,08\% of total number of hours was given for humanities in the first year, $22,06 \%$ during the second year, 9,85\% in the third year, and $13,26 \%$ in the fourth year in the specialty 0514 and $12,87 \%$ in specialties 0504,0525 , in the fifth year $-15,44 \%$ in specialty $0514,15,75 \%$ in specialty $0504,15,11 \%$ in specialty 0525 , in the sixth year $-2,88 \%$ in specialty $0514,2,7 \%$ in specialty $0504,2,41 \%$ in specialty 0525 .

In the curriculum of 1978-1979 in the first year, the humanities included: history of the CPSU - 46 hours, which was $9,58 \%$ of the total number of hours with the credit in the I semester and the exam in the II semester; foreign language - 60 hours with a rate of 12,5\% with credits in the I and the II semesters. In the second year: history of the CPSU - 36 hours or $6,62 \%$ with the exam in the III semester; Marxist-Leninist philosophy - 16 hours or $2,94 \%$ with the credit in the IV semester; foreign language - 68 hours or $12,5 \%$ with the credit in the III semester and the exam in the IV semester. In the third year: philosophy and scientific atheism - 54 hours or $9,85 \%$ with exams in the V and the VI semesters. 
Table 2

Education in the humanities of the Kherson branch of the Nikolayev Admiral S. Makarov Shipbuilding Institute (1973-1983)

\begin{tabular}{|c|c|c|c|c|c|}
\hline $\begin{array}{c}\text { Educational } \\
\text { year }\end{array}$ & Specialty & $\begin{array}{c}\text { Year of } \\
\text { education }\end{array}$ & $\begin{array}{c}\text { Total number of } \\
\text { hours }\end{array}$ & $\begin{array}{l}\text { Hours which } \\
\text { are given to the } \\
\text { humanities }\end{array}$ & $\begin{array}{l}\text { The proportion of the } \\
\text { humanities in the total } \\
\text { hours of the curriculum, \% }\end{array}$ \\
\hline \multirow{12}{*}{$1973-1974$} & \multirow{12}{*}{$\begin{array}{l}0514 \\
0504 \\
0525\end{array}$} & I & 512 & 144 & 28,13 \\
\hline & & II & 560 & 140 & 25 \\
\hline & & III & 560 & 105 & 18,75 \\
\hline & & & 560 & 57 & 10,18 \\
\hline & & IV & 558 & 57 & 10,22 \\
\hline & & & 560 & 57 & 10,18 \\
\hline & & & 541 & 0 & 0 \\
\hline & & V & 560 & 0 & 0 \\
\hline & & & 589 & 0 & 0 \\
\hline & & & 332 & 70 & 21,08 \\
\hline & & VI & 336 & 70 & 20,83 \\
\hline & & & 374 & 32 & 8,56 \\
\hline \multirow{12}{*}{ 1978-1979 } & \multirow{12}{*}{$\begin{array}{l}0514 \\
0504 \\
0525\end{array}$} & I & 480 & 106 & 22,08 \\
\hline & & II & 544 & 120 & 22,06 \\
\hline & & III & 548 & 54 & 9,85 \\
\hline & & IV & 528 & 70 & 13,26 \\
\hline & & & 544 & 70 & $12,87 \%$ \\
\hline & & & 544 & 70 & 12,87 \\
\hline & & & 544 & 84 & 15,44 \\
\hline & & V & 546 & 86 & 15,75 \\
\hline & & & 556 & 84 & 15,11 \\
\hline & & & 278 & 35 & 12,59 \\
\hline & & VI & 296 & 35 & 11,82 \\
\hline & & & 332 & 35 & 10,54 \\
\hline \multirow{12}{*}{$1983-1984$} & \multirow{9}{*}{$\begin{array}{l}0514 \\
0504 \\
0525\end{array}$} & I & 512 & 112 & 21,88 \\
\hline & & & 546 & 120 & 21,98 \\
\hline & & II & 546 & 120 & 21,98 \\
\hline & & & 544 & 120 & 22,06 \\
\hline & & III & 544 & 50 & 9,19 \\
\hline & & IV & 544 & 70 & 12,87 \\
\hline & & & 544 & 116 & 21,32 \\
\hline & & V & 544 & 100 & 18,38 \\
\hline & & & 544 & 100 & 18,38 \\
\hline & & & 256 & 8 & 2,88 \\
\hline & & VI & 256 & 8 & 2,7 \\
\hline & & & 256 & 8 & 2,41 \\
\hline
\end{tabular}

In the 4th year: political economy -70 hours or $13,26 \%$ in the specialty 0514,70 hours or $12,87 \%$ in the specialty 0504,70 hours or $12,87 \%$ in the specialty 0525 with the exam in the VII semester and the credit in the VIII semester. In the 5th year: scientific communism - 52 hours 
or $9,56 \%$ in the specialty 0514,54 hours or $9,89 \%$ in the specialty 0504,52 hours or $9,35 \%$ with the credit in the IX and the X semesters; economics of the shipbuilding industry - 32 hours or $5,88 \%$ in the specialty $0514,5,86 \%$ in the specialty $0504,5,76 \%$ in the specialty 0525 with the exam in the $\mathrm{X}$ semester. In the 6th year: review lectures on scientific communism -8 hours or $2,88 \%$ in the specialty $0514,2,7 \%$ in the specialty $0504,2,41 \%$ in the specialty 0525 with the state exam in the XII semester.

In the 1983-1984 academic year, 21,88\% of total number of hours was given for humanities in the first year, $21,98 \%$ in the second year, $9,19 \%$ in the third year, $12,87 \%$ in the fourth year, and $21 \%$ in the fifth year, $32 \%$ in the specialty $0514,18.38 \%$ in the specialty 0504,0525 , in the sixth year $12,5 \%$ in the specialty $0514,0504,18,75 \%$ in the specialty 0525 .

In the curriculum of 1983-1984 in the first year, the humanities included: history of the CPSU -48 hours, which was $9,38 \%$ of the total number of hours with the exam in the II semester; foreign language - 64 hours with a rate of $12,5 \%$ with credits in the I and the II semesters. In the second year: history of the CPSU - 36 hours or $6,59 \%$ in specialties 0514,0504 and 36 hours or $6,62 \%$ in specialty 0525 with the exam in the III semester; Marxist-Leninist philosophy -16 hours or $2,93 \%$ in specialties 0514,0504 and 16 hours or $2,94 \%$ in specialty 0525 ; foreign language - 68 hours or $12,45 \%$ in specialties 0514,0504 and 68 hours or $12,5 \%$ in specialty 0525 with the credit in the III semester and the exam in the IV semester.

In the third year: Marxist-Leninist philosophy - 50 hours or $9,19 \%$ with exams in the $\mathrm{V}$ and the VI semesters. In the fourth year: political economy - 70 hours or $12,87 \%$ with the exam in the VII semester and the credit in the VIII semester. In the 5th year: scientific communism - 32 hours or 5,88\% with the credit in the X semester; economics of the industry 32 hours or $5,88 \%$ with the exam in the X semester; political economy -36 hours or $6,62 \%$ with the exam in the IX semester; Soviet law -16 hours or $2,94 \%$ with the credit in the X semester in specialty 0514 and the same indicators in specialties 0514 and 0504 , but without the discipline of Soviet law. In the 6th year: scientific communism - 32 hours or $12,5 \%$ with the credit in the IX semester and the state exam in the X semester in the specialty 0514, 0504, scientific communism -32 hours or $12,5 \%$ with the credit in the IX semester and the state exam in X semester in specialty 0525 ; Soviet law -16 hours or $6,25 \%$ with the credit in the IX semester.

\section{Conclusions}

Thus, the article analyzes the education in the humanities (1973-1983) in maritime educational institutions of Ukraine. The humanities included both classical (foreign language, history, philosophy, etc.) and modern (political economy, economics of the industry, law, etc.) subjects. After analyzing the hours which are given to the humanities in maritime educational institutions and examining proportion of the humanities in the total hours of the curriculum, we found that small amounts of hours were allocated to the humanities in the curriculum. During this period, the Soviet Navy was accepted into a number of international organizations, so hours for the study of foreign languages and maritime law were allocated. The fleet included specialized vessels, so in the curriculum a significant part of the hours were allocated to general special and profiling subjects. New methods of labor and industry organization were also used, so the discipline of economics of industry was studied. Of course, much attention was paid to ideological disciplines, such as the history of the CPSU, Marxist-Leninist philosophy, scientific communism, and atheism.

The prospects of further research are the study of trends of the development of the education in the humanities in maritime educational imstitutions at other historical stages and their comparison. 


\section{References}

Istoriya flota Rossii [History of the Russian fleet]. Retrieved from https://www.mintrans.gov.ru/ flot/ [in Russian].

Lukov Vl. (2005). Reformy obrazovaniya [Education reform]. Znanie. Ponimanie. Umenie. [in Russian].

Liashkevych, A. I. (2018). Stanovlennia i rozvytok morskoi osvity na Khersonshchyni [Formation and development of maritime education in the Kherson region]. Kherson: KVNZ "Khersonska akademiia neperervnoi osvity". [in Ukrainian]

Rabochie uchebnye plany Khersonskogo filiala Nikolaevskogo korablestroitel'nogo institute imeni admirala S. O. Makarova $1973 \backslash 1974 \mathrm{~g}$. [Curriculum of the Kherson branch of the Nikolaev Admiral S.O. Makarov Shipbuilding Institute] (Fund 3986 Derzhavnyi arkhiv Khersons'koi oblasti 1 File 76. State Archive of Kherson region, Kherson [in Russian].

Rabochie uchebnye plany Khersonskogo filiala Nikolaevskogo korablestroitel'nogo institute imeni admirala S. O. Makarova $1974 \backslash 1975 \mathrm{~g}$. [Curriculum of the Kherson branch of the Nikolaev Admiral S. Makarov Shipbuilding Institute] (Fund 3986 Derzhavnyi arkhiv Khersons'koi oblasti 1 File 94. State Archive of Kherson region, Kherson [in Russian].

Rabochie uchebnye plany Khersonskogo filiala Nikolaevskogo korablestroitel'nogo institute imeni admirala S. O. Makarova $1975 \backslash 1976 \mathrm{~g}$. [Curriculum of the Kherson branch of the Nikolaev Admiral S. Makarov Shipbuilding Institute] (Fund 3986 Derzhavnyi arkhiv Khersons'koi oblasti 1 File 106. State Archive of Kherson region, Kherson [in Russian].

Rabochie uchebnye plany Khersonskogo filiala Nikolaevskogo korablestroitel'nogo institute imeni admirala S. O. Makarova $1976 \mid 1977 \mathrm{~g}$. [Curriculum of the Kherson branch of the Nikolaev Admiral S. Makarov Shipbuilding Institute] (Fund 3986 Derzhavnyi arkhiv Khersons'koi oblasti 1 File 113. State Archive of Kherson region, Kherson [in Russian].

Rabochie uchebnye plany Khersonskogo filiala Nikolaevskogo korablestroitel'nogo institute imeni admirala S. O. Makarova 1977\1978 g. [Curriculum of the Kherson branch of the Nikolaev Admiral S. Makarov Shipbuilding Institute] (Fund 3986 Derzhavnyi arkhiv Khersons'koi oblasti 1 File 125. State Archive of Kherson region, Kherson [in Russian].

Rabochie uchebnye plany Khersonskogo filiala Nikolaevskogo korablestroitel'nogo institute imeni admirala S. O. Makarova $1978 \backslash 1979 \mathrm{~g}$. [Curriculum of the Kherson branch of the Nikolaev Admiral S. Makarov Shipbuilding Institute] (Fund 3986 Derzhavnyi arkhiv Khersons'koi oblasti 1 File 133. State Archive of Kherson region, Kherson [in Russian].

Rabochie uchebnye plany Khersonskogo filiala Nikolaevskogo korablestroitel'nogo institute imeni admirala S. O. Makarova $198011981 \mathrm{~g}$. [Curriculum of the Kherson branch of the Nikolaev Admiral S. Makarov Shipbuilding Institute] (Fund 3986 Derzhavnyi arkhiv Khersons'koi oblasti 1 File 149. State Archive of Kherson region, Kherson [in Russian].

Rabochie uchebnye plany Khersonskogo filiala Nikolaevskogo korablestroitel'nogo institute imeni admirala S. O. Makarova $1973 \backslash 1974 \mathrm{~g}$. [Curriculum of the Kherson branch of the Nikolaev Admiral S. Makarov Shipbuilding Institute] (Fund 3986 Derzhavnyi arkhiv Khersons'koi oblasti 1 File 76. State Archive of Kherson region, Kherson [in Russian].

Rabochie uchebnye plany Khersonskogo filiala Nikolaevskogo korablestroitel'nogo institute imeni admirala S. O. Makarova $1983 \backslash 1984 \mathrm{~g}$. [Curriculum of the Kherson branch of the Nikolaev Admiral S. Makarov Shipbuilding Institute ] (Fund 3986 Derzhavnyi arkhiv Khersons'koi oblasti 1 File 175. State Archive of Kherson region, Kherson [in Russian].

Uchebnyi plan spetsial'nosti "Sudovozhdenie" (1972) [Curriculum of the specialty "Navigation"]. Moskva [in Russian].

Uchebnyi plan spetsial'nosti "Sudovozhdenie" (1982) [Curriculum of the specialty "Navigation"]. Moskva [in Russian]. 